\title{
PENGEMBANGAN DESA WISATA DI KAWASAN AGROWISATA: PERSPEKTIF TEORI STRUKTURASI
}

\author{
Kusuma Astuti \\ Universitas Sebelas Maret (UNS) \\ Email: uthie.ip@gmail.com \\ Ismi Dwi Astuti Nurhaeni \\ Universitas Sebelas Maret (UNS) \\ Email: ismidwiastuti@staff.uns.ac.id \\ Andre Noevi Rahmanto \\ Universitas Sebelas Maret (UNS) \\ Email: andreyuda@gmail.com
}

\begin{abstract}
The second largest foreign exchange earner from the tourism sector. The tourism sector in Indonesia grown by $25.68 \%$ in recent years. Very much different from the growth of the tourism industry in Southeast Asia that only $7 \%$, as well as the growth of the world tourism industry which is only $6 \%$. Opportunities in the tourism sector are quite prospective, in addition to being one of the producers of economic growth, the tourism sector is expected to encourage the growth of other sectors, such as the plantation, agriculture, trade, industry and others. This study was analyzed using structuration theory that aims to find out how the communication made by agents in the development of Pulesari Tourism Village, Turi District, Sleman Regency, Special Region of Yogyakarta. The method used in this research is a qualitative method with a case study approach. Research data obtained from field observations, in-depth interviews, and documentation. The results of the study explain how the structuring process that takes place through the rural tourism program can improve the village economy, and have an impact on increasing the income of its people by increasing employment opportunities.
\end{abstract}

Keywords: Structuration, Agro-tourism Development, Tourism Village 


\section{Pendahuluan}

Menurut World Travel \& Tourism Council pariwisata di Indonesia berada di posisi sembilan dunia, posisi tiga di Asia, dan menduduki peringkat teratas di Asia Tenggara. Telegraph yang merupakan media terkemuka di Inggris menilai Indonesia sebagai salah satu negara yang pertumbuhan pariwisatanya tercepat dari 20 negara. GMTI (Global Muslim Travel Index) juga memilih Indonesia dan Malaysia sebagai peringkat pertama, negara dengan wisata halal dunia di 2019. World Economy Forum (WEF) berpendapat perkembangan pariwisata di Indonesia naik delapan poin dari 50 di 2015 menjadi peringkat 42 pada 2017. (Rahmadi, 2019).

Daerah Istimewa Yogyakarta (DIY) merupakan wilayah dengan destinasi wisata yang banyak diminati oleh wisatawan. Kunjungan wisatawan yang terus meningkat setiap tahunnya membuktikan DIY berpeluang menjadi daerah wisata unggulan di Indonesia. Salah satu wisata yang saat ini tengah diminati wisatawan adalah desa wisata. Salah satu desa wisata yang terus meningkat kunjungannya adalah Desa Wisata di Sleman. Dari tahun ketahun semakin banyak wisatawan baik wisatawan nasional maupun wisatawan mancanegara yang berkunjung ke Desa Wisata di Sleman, data tersebut dapat dilihat pada Tabel 1 berikut:

Tabel 1. Kunjungan Wisatawan ke Desa Wisata di Sleman Tahun 2014-2018

\begin{tabular}{cc} 
Tahun & Kunjungan Wisatawan \\
\hline 2014 & 16.251 .170 \\
2015 & 18.538 .330 \\
2016 & 20.710 .976 \\
2017 & 25.950 .793 \\
2018 & 26.515 .788 \\
\hline
\end{tabular}

Sumber: Dinas Pariwisata Sleman, 2019 
Desa Wisata Pulesari berdiri berawal dari gagasan para pemuda di Dusun Pulesari yang ingin menjadikan dusunnya sebagai Desa Wisata. Gagasan tersebut muncul dari keperihatinan para pemuda terhadap dampak pasca erupsi gunung merapi pada tahun 2010 yang menyebabkan perekonomian di desa tersebut lumpuh. Sebagian besar penduduk Dusun Pulesari yang merupakan petani salak tidak dapat melakukan aktifitas pertanian karena, perkebunan salak yang mereka miliki rusak akibat tertimbun abu vulkanik pasca erupsi gunung merapi. Sehingga banyak masyarakat petani yang beralih pekerjaan sebagai pekerja bangunan.

Petani yang sudah tidak tidak bekerja lagi sebagai petani, beralih pekerjaan ke sektor informal karena tidak memiliki keterampilan sehingga sulit masuk ke sektor jasa. Hal tersebut berdampak dengan meningkatnya kemiskinan di pedesaan (Janah, Eddy dan Dalmiyatun, 2017). Namun, program agrowisata memberikan kesempatan kerja dan kewirausahaan bagi penduduk setempat, perlindungan alam dan dampak rendah terhadap lingkungan dan budaya (Arifin dan Yen, 2017). Dengan terbukanya kesempatan kerja akan meningkatkan kesejahteraan masyarakat terutama masyarakat yang bekerja di sektor pertanian. Adanya perkembangan kegiatan di sekor pariwisata dan pemerataan pembangunan membuat sektor pertanian tidak terpinggirkan. Kecenderungan pergeseran minat wisatawan akan permintaan agrowisata juga membuka peluang pengembangan produk-produk pertanian. Pada dasarnya agrowisata memanfaatkan potensi atraksi wisata pertanian.

Dalam Pariwisata, Sumber daya Manusia sebagai salah satu bagian yang terpenting sebagai alat untuk meningkatkan bagaimana mutu dari suatu kualitas produk itu ditentukan oleh bagaimana kualitas sumber daya manusia menentukan mutu dari kualitas produk Pariwisata (Anugrah dan Sudarmayasa, 2017). Untuk itu, edukasi kepada masyarakat terkait program desa wisata terus dilakukan untuk berlangsungnya pariwisata yang berkelanjutan. Melalui program pendidikan dan pelatihan diharapkan kemampuan sumber daya manusia yang dimiliki akan semakin baik dan menjadi ahli dalam bidangnya. Bongkar pasang dalam struktur organisasi 
juga terus dilakukan untuk memilih orang-orang yang memang berkompeten dalam bidangnya. Perkembangan pariwisata juga dapat meningkatkan sektor pendapatan rumah tangga, perbaikan dari segi perumahan, lingkungan hidup yang lebih layak, kehidupan sosial masyarakat yang lebih terarah ke kegiatan positif dalam pengembangan kreativitas dan industri rumah tangga, penanganan kesehatan yang lebih diperhatikan, kesadaran akan pendidikan yang lebih baik, dan kesempatan kerja dalam sektor jasa pariwisata, walaupun dengan berbagai keterbatasan yang dimiliki oleh masyarakat (Tibuludji, Mahendara dan Adhika, 2017)

Dalam penelitian ini, teori strukturasi digunakan untuk menganalisis bagaimana proses strukturasi yang berlangsung dalam pengembangan desa wisata sehingga dapat meningkatkan perekonomian desa, dan berdampak pada meningkatnya penghasilan masyarakatnya. Dengan menganalisis strukturasi pengembangan desa wisata sebagai suatu sistem, maka dapat diketahui bagaimana sistem di produksi dan direproduksi melalui interaksi para agen. Penelitian ini berusaha menggambarkan dan memberikan pemahaman bagaimana proses dinamika pengembangan Desa Wisata Pulesari di Dusun Pulesari dengan adanya perubahan karena proses strukturasi.

\section{Landasan Teori}

\section{Perspektif Teori Strukturasi}

Pertentagan tajam antara stuktur fungsional dengan konstuksionisme fenomenologis dapat ditepis oleh teori strukturasi. Sturktur dalam teori ini bukanlah sebuah kekangan, namun dapat bersifat mengekang juga membebaskan. Sifat-sifat sturktur sistem sosial terkait dengan ruang dan waktu yang tidak dapat ditentukan oleh aktor-aktor individu (Giddens, 2011). Dalam teori ini tindakan yang dilakukan agen (manusia) secara sengaja dan mampu mengungkapkan alasan-alasan atas aktivitas-aktivitasnya secara berulang-ulang untuk mencapai tujuan. Tindakan agen 
tersebut dapat berakibat tindakan yang tidak disengaja dan berdampak kepada tindakan agen selanjutnya.

Teori dalam strukturasi mengacu pada suatu cara bagaimana suatu struktur sosial diproduksi dan direproduksi melalui praktik atau tindakan. Hal ini berarti, saat seseorang berkomunikasi dengan orang lain, akan tercipta struktur dengan hubungan individu yang lebih kecil, hal tersebut memberi jarak kepada lembaga sosial budaya yang lebih besar. Struktur dapat diibaratkan hubungan antara peran kelompok dan lembaga masyarakat. Hubungan tersebut, merupakan hubungan yang dapat mempengaruhi dan dipengaruhi dengan tindakan sosial. Struktur memberikan aturan sebagai dasar tindakan individu, seiring berjalannya waktu dan praktek tindakan sosial yang dilakukan individu, mereka memproduksi aturan baru, lalu mereproduksi aturan yang lama (Littlejhon \& Foss, 2011).

Dasar dari teori ini adalah perbedaan antara sistem, struktur, dan praktek. Sistem merupakan seperangkat pola normal pertukaran yang menghubungkan orang, perilaku, pesan, hubungan, dan hal-hal termasuk keduanya elemen manusia dan bukan manusia. Struktur dibedakan dari sistem dengan menjadi diam-diam dan memberdayakan. Ini merupakan domain aturan dan sumber daya agen mana yang menarik untuk bertindak. Aturan merupakan prinsip atau rutinitas yang dapat memandu atau melandaskan tindakan; sumberdaya adalah apapun yang dapat digunakan atau diadaptasi oleh orang dalam tindakan (Littlejhon \& Foss, 2009).

Penelitian ini akan mengaitkan antara program desa wisata yang dilakukan di Dusun Pulesari dalam pandangan teori sturkturasi. Tidak hanya sturktur, agen juga memiliki peran dalam menjalankan program pengembangan Desa Wisata. Pihakpihak yang terlibat dalam pengembangan Desa Wisata Pulesari merupakan agen. Pihak-pihak yang dimaksud meliputi Ketua Desa Wisata Pulesari, RT Dusun Pulesari, RW Dusun Pulesari, Dukuh Dusun Pulesari dan Masyarakat Dusun Pulesari. 
Struktur yang dimaksudkan dalam penelitian ini adalah stigma yang ada dalam masyarakat bahwa menjadi masyarakat desa tidak akan bisa memiliki perekonomian cukup, terlebih jika pekerjaannya hanya sebagai petani. Terdapat tiga dimensi sturktural dalam struktur sistem sosial, yaitu: signifikansi, dominasi serta legitimasi (Littlejhon \& Foss, 2011; Barker, 2011). Signifikansi menyatakan bagaimana agen memahami sesuatu. Sedangkan dominasi menyatakan bagaimana agen menunjukkan sesuatu itu dilakukan. Legitimasi menyatakan bagaimana cara agen mencapai suatu keinginan. Dari ketiga struktur tersebut, terjadilah proses pengembangan desa wisata yang ditujukan untuk peningkatan pendapatan masyarakat desa yang pada akhirnya menjadi suatu praktik sosial. Giddens mengatakan dalam strukturasi terdapat dualitas struktur, yang merupakan usaha dalam menghubungan agen dan struktur (Giddens, 2011).

\section{Pengembangan Desa Wisata di Kawasan Agrowisata}

Agrowisata merupakan potensi pertanian yang meliputi keunikan dan keanekaragaman aktivitas produksi dan teknologi pertanian, panorama alam kawasan pertanian, serta budaya masyarakat pertaniannya yang dijadikan sebuah rangkaian kegiatan wisata (Palit et al., 2017). Pendapat lain mengatakan bahwa agrowisata merupakan salah satu bentuk rular tourism yang melibatkan penduduk lokak dapam perencanaan hingga pengelolaan kawasan agrowisata yang menawarkan kegaitan pertanian sebagai daya tarik wisata. Selain itu, agrowisata berpotensi untuk meningkatkan sumber pendapatan dan keuntungan masyarakat. Secara tidak langsung meningkatakan nilai produk-produk pertanian karena pengunjung dapat berhubungan langsung dengan para petani di kawasan agrowisata (Andini, 2013).

Pengembangan agrowisata dapat dilakukan dengan mengintegrasikan sektorsektor terkait (pertanian, peternakan, perikanan, perhotelan, biro perjalanan, industri, kesenian dan kebudayaan dan segala hal yang terkait dengan kewilayahan dan 
keterpaduan dalam pengelolaan kawasan agrowisata). Sektor lain (agropolitan, perkebunan, tanaman pangan, hotikultura, peternakan, perikanan) juga dapat dikembangkan sebagai kawasan agrowisata yang diharapkan mampu menunjang pengembangan ekonomi secara berkelanjutan (Chamdani, 2018).

Berikut ini merupakan kriteria kawasan agrowisata (Chamdani, 2018):

1. Basis kawasan atau memiliki potensi di sektor agro (sektor peternakan, perikanan, hotikultura dan pertanian), seperti:

a. Sub sistem usaha pertanian primer (pertanian tanaman pangan, hortikultura, perkebunan, perikanan, peternakan, dan kehutanan).

b. Sub sistem industri pertanian (industri pengolahan, kerajinan, pengemasan, dan pemasaran baik lokal maupun ekspor).

c. Sub sistem pelayanan yang dapat mendukung dan menunjang kesinambungan terhadap layanan dan industri wisata maupun sektor agro (transportasi dan akomodasi, penelitian dan pengembangan, perbankan dan asuransi, fasilitas telekomunikasi dan infrastruktur).

2. Kegiatan yang paling banyak dilakukan adalah kegiatan pertanian yang dilakukan oleh masyarakat dan adanya kegiatan wisata dengan keterkaitan dan ketergantungan yang cukup tinggi. Kegiatan pertanian yang mendorong tumbuhnya industri pariwisata, dan sebaliknya kegiatan pariwisata yang memacu perkembangannya sektor agro.

3. Memiliki interaksi yang intensif dan saling mendukung, antara kegiatan agro dan kepariwisataan pada kawasan itu. Kegiatan yang beraneka ragam tersebut dan produk wisata merupakan hal yang dapat dikembangkan secara berkelanjutan.

Agrowisata berkelanjutan berdampak positif, agrowisata melindungi lingkungan dan keanekaragaman hayati, lanskap serta sumber daya alam. Agrowisata juga berhasil mempromosikan pembangunan (Giaccio et al., 2015). 
Agrowisata mendatangkan banyak dampak positif bagi perkembangan desa. Dampak dari pengembangan kawasan agrowisata diantaranya adalah sebagai pusat kegiatan suatu kelompok masyarakat, meningkatkan peran dan partisipasi masyarkat dan kelompok tani, meningkatakan produksi dan kualitas produk pertanian, menciptakan lapangan kerja baru serta meningkatkan pendapatan petani dan masyarakat setempat, daya dukung promosi terkait pertanian unggulan, meningkatkan kegiatan penelitian ilmiah dan ilmu pengetahuan, melestarikan potensi dan sumber daya alam daerah. Seni dan budaya pertanian turun temurun juga terdorong untuk tumbuh dan berkembang (Pambudi et al., 2018).

Sementara itu, desa wisata merupakan wilayah pedesaan yang menawarkan suasana asli desa dan memiliki daya tarik wisata, dan wisatawan dapat menginap di desa wisata (Sudarmadji, 2014). Dalam mengembangkan desa wisata diperlukan kajian sehingga dampaknya dapat dikontrol, pengkajian dilakukan dengan cara memperhatikan faktor daya dukung dan keberlangsungan. Selain itu menimbang apakah desa tersebut dapat memberikan manfaat ekonomi kepada masyarakat desa baik secara langsung dan tidak. Maka, dalam pengembangan desa wisata penting untuk memberdayakan masyarkatnya (Dinas Pariwisata DIY, 2014).

Potensi alam yang dimiliki Dusun Pulesari diantaranya adalah kawasan pertanian salak, kawasan lereng merapi, dan sungai. Potensi seni dan budaya yang dimiliki Dusun Pulesari diantaranya adalah (1) Seni Pertunjukan Kerakyatan yang meliputi Tari Salak, Kubro Siswo, Bregodo, Klentingsari dll, (2) Upacara Adat yang meliputi Upacara Adat Pager Bumi dan Sadranan, (3) Tradisi Kearifan Lokal Masyarakat yang meliputi Mitoni, Kenduri, Gotong Royong, dll, (4) Petilasan dan Sejarah yang meliputi Goa Alam, Makan Nyai.Pulesari, Sumur Tua, dll. Sedangkan potensi pendukung yang dimiliki Dusun Pulesari diantaranya adalah (1) Layanan Penginapan Homestay yang merupakan Penginapan Milik Warga Masyarakat. (2) Layanan Kegiatan Edukasi seperti membatik, belajar kerajinan, belajar kuliner, dll. 
Dengan segala potensi yang dimiliki Dusun Pulesari diharapkan dapat dikelola dan dimanfaatkan dalam upaya peningkatan pendapatan masyarakat desa.

\section{Metode Penelitian}

Penelitian ini di lakukan di Desa Wisata Pulesari, Desa Wonokerto, Kecamatan Turi, Kabupaten Sleman, Provinsi Daerah Istimewa Yogyakarta. Metode yang digunakan dalam penelitian ini adalah kualitatif, dengan pendekatan studi kasus. Studi kasus digunakan sebagai instrumen untuk menggambarkan proses strukturasi di Desa Wisata Pulesari, yaitu bagaimana hubungan aktor, agen dan struktur sehingga menciptakan realitas sosial dalam pengembangan agrowisata. Realitas sosial yang tercipta menjadikan Desa Wisata Pulesari sebagai desa wisata dengan kunjungan tertinggi di Sleman selama lima tahun terakhir hingga saat ini, sehingga meningkatkan perekonomian masyarakat dan desa. Penelitian ini dilakukan mulai September hingga November 2019.

Sumber data primer yang digunakan dalam penelitian ini meliputi dokumentasi, observasi dan wawancara mendalam. Sedangkan, data sekunder diperoleh melalui jurnal terkait, buku teks, dan referensi profesional lainnya. Sampling dalam penelitian ini menggunakan teknik purposive sampling. Peneliti menetapkan kriteria yang harus dipenuhi oleh informan sebelum melakukan penelitian. Peneliti juga mengetahui siapa saja yang akan dijadikan informan sebelum melakukan penelitian. (Afrizal, 2015). Validitas data dalam penelitian ini menggunakan trianggulasi sumber. Informan dalam penelitian ini meliputi Ketua Desa Wisata Pulesari, Wakil Ketua Dusun Pulesari, Dukuh Dusun Pulesari, Ketua RT Dusun Pulesari dan 4 (empat) orang masyarakat Dusun Pulesari. 


\section{Hasil dan Pembahasan}

\section{Pengembangan Desa Wisata Pulesari Sebagai Upaya Meningkatkan Pendapatan Masyarakat Desa}

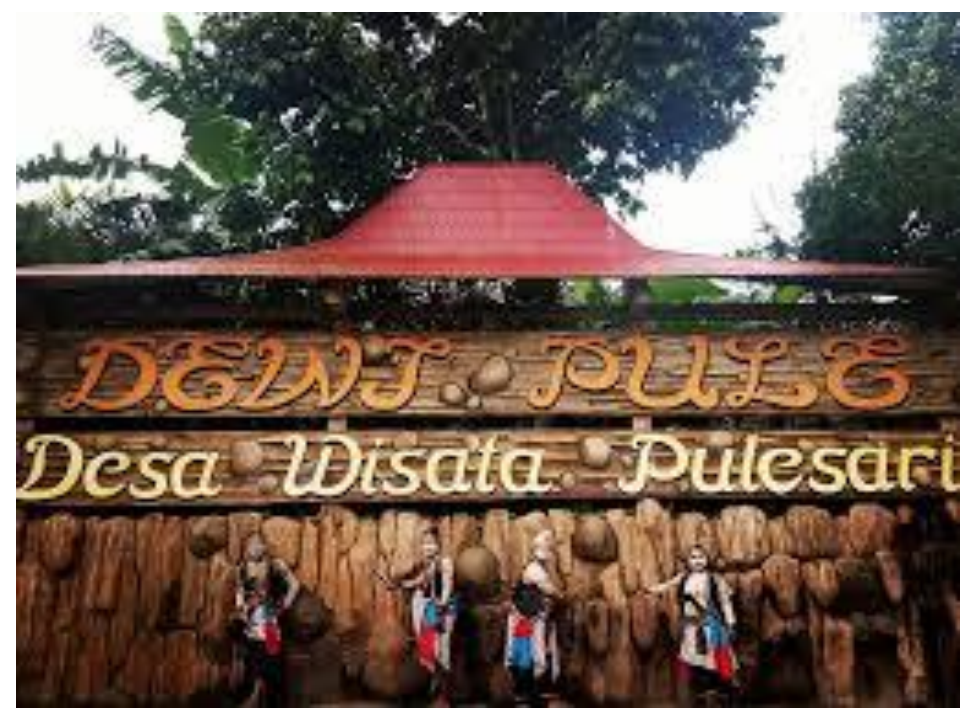

Gambar 1. Spot Icon Desa Wisata Pulesari Sumber: Dokumentasi Desa Wisata Pulesari

Keberadaan Desa Wisata Pulesari merupakan gagasan dari para pemuda di Dusun Pulesari untuk menjadikan desanya sebagai desa wisata. Gagasan tersebut muncul ketika pasca erupsi gunung merapi pada tahun 2010 menyebabkan perekonomian di desa tersebut lumpuh. Sebagian besar penduduk Dusun Pulesari yang merupakan petani salak kesulitan untuk melanjutkan aktifitas budidaya salak karena, perkebunan salak yang mereka miliki rusak akibat tertimbun abu vulkanik pasca erupsi gunung merapi. Sayangnya pada awal gagasan ini disosialisasikan, banyak masyarakat desa yang belum setuju akan program desa wisata yang hendak dilaksanakan di Dusun Pulesari. Namun, inisiator desa wisata tersebut terus melakukan sosialisasi di berbagai pertemuan di desa, misalnya pertemuan arisan, pertemuan RT, pertemuan RW maupun pertemuan yang diadakan Dukuh setempat. Setelah melakukan sosialisasi yang terus menerus mengenai pemahaman konsep desa 
wisata. Akhirnya, pada 9 November 2012 Dusun Pulesari resmi diresmikan oleh Bapak Camat Turi menjadi Desa Wisata Pulesari.

Selanjutnya disepakati berdasarkan musyawarah bahwa Desa Wisata Pulesari mengusung konsep sebagai desa wisata alam, budaya, dan tradisi. Konsep tersebut diusung karena merupakan kearifan lokal di desa tersebut. Kearifan lokal dimaknai sebagai pengetahuan yang dimiliki dan didapat oleh masyarakat setempat melalui pengalaman dan percobaan yang telah dilalui serta integrasi pemahaman terhadap budaya dan alam sekitarnya (Setyawati, 2014). Tujuan dari dibentuknya Desa Wisata Pulesari ini adalah bagaimana agar dapat mengedukasi masyarakat atau memberikan kegiatan apa yang dapat berkontribusi untuk desa dan masyarakat terutama dapat memberikan perubahan ekonomi yang lebih baik untuk desa dan masyarakat. Sehingga kegiatan tersebut dapat menjadi sumber keuangan sendiri bagi desa dan masyarakat. Target kedepannya diharapkan wisata ini dapat mensejahterakan masyarakat dengan memberdayakan sumber manusia dan sumber daya alam yang dimiliki.

Setiap individu dapat diberdayakan dengan pengetahuan yang diperluas, keterampilan, aspirasi, dan konsep diri dan agensi pribadi. Tetapi pemberdayaan individu dimulai dari pembelajaran dalam kelompok, termasuk pengetahuan, keterampilan, aspirasi, dan konsep diri tentang bagaimana caranya bekerja bersama dengan orang lain, bagaimana melakukan tindakan kolektif yang efektif. Tindakan kolektif yang efektif menciptakan kondisi bagaimana dapat memberdayakan individu, termasuk kapasitas mereka untuk diberdayakan secara kolektif. Interaksi pemberdayaan individu dan pemberdayaan kolektif merupakan pemberdayaan masyarakat (Cislaghi, et. al., 2016). Dengan memberdayakan masyarakat desa sesuai potensi yang dimilikinya melalui kelompok sadar wisata (pokdarwis) yang ada di Dusun Pulesari, diaharapkan dapat mempercepat pengembangan Desa Wisata Pulesari. 
Saat ini, setiap anggota/masyarakat di Dusun Pulesari telah memiliki perannya masing-masing dalam mengembangkan desa wisata. Di Desa Wisata Pulesari seluruh masyarakat desa diharuskan berperan aktif dalam mendukung berkembangnya desa wisata. Peran serta masyarakat/anggota yang masuk dalam kelembagaan disesuaikan dengan kemampuan mereka, dengan keahlian yang mereka miliki, tidak berbasis pada pendidikan yang berdasarkan ijazah. Pada awal kepengurusan organisasi dibentuk, pemilihan ketua, wakil ketua, sekretaris, bendahara, dan seksi-seksi dilakukan secara musyawarah seluruh masyarakat desa. Selanjutnya dalam perjalanannya ketua diberi kewenangan untuk mengganti anggota-anggotanya demi keberlangsungan organisasi agar dapat berjalan dengan baik. Misalkan jika seseorang berbakat dibidang pertukangan dimasukkan ke seksi pengembangan infrastruktur, selanjutnya jika seseorang berbakat di bidang IT akan dimasukkan ke seksi promosi atau sekretaris, selanjutnya jika bakatnya berbicara dijadikan trainer, selanjutnya jika seseorang bakat di bidang pengembangan makan dimasukkan ke seksi pengembangan outbond atau pengembangan atraksi.

Kegiatan yang dilakukan Desa Wisata Pulesari setiap hari yaitu kegiatan penerimaan kunjungan. Seiring dengan dibentuknya Desa Wisata maka terbentuk kelompok sadar wisata (Pokdarwis) dengan keluarnya SK. Kepala Dinas Kebudayaan dan Pariwisata Kabupaten Sleman Nomor 556/10/2015 pada 2 Januari 2015. Melalui kelompok sadar wisata Desa Wisata Pulesari membuat program jangka pendek, jangka menengah, dan jangka panjang yang diharapkan dapat terus mengembangkan desa wisatanya. Program tersebut tercatat dalam rencana program kerja setiap tahunnya. Contoh program jangka panjangnya yaitu akan melakukan pengadaan lahan untuk fasilitas desa wisata yaitu, Desa Wisata Pulesari sedang berusaha untuk membeli lahan milik masyarakat pendatang yang tidak digunakan untuk dijadikan fasilitas bumi perkemahan, karena Desa Wisata Pulesari tidak memiliki tanah kas desa. Selain itu pemberdayaan masyarakat untuk mengembangkan fasilitas koperasi 
desa, sehingga masyarakat dapat melakukan aktivitas simpan pinjam di koperasi tersebut.

Program jangka menengah meliputi program infrasturktur, kemudian kegiatan pemberdayaan masyarakat, lalu penempatan kapasitas masyarakat. Salah satu bentuk program infrastruktur yang sudah dilakukan yaitu fokus pada pembenahan infrastruktur fasilitas pendopo, perbaikan fasilitas wahana outbond di sungai, pembuatan spot selfie yang terbuat dari bamboo, pengadaan soundsistem, pemasangan papan petunjuk arah, kemudian tamanisasi pagar desa yang sudah dilaksanakan $100 \mathrm{~m}^{2}$ dari bawah dan $100 \mathrm{~m}^{2}$ ke atas, kanan kiri jalan ditanami pepohonan untuk mempercantik pintu masuk ke arah Desa Wisata Pulesari. Selain itu, program infrastrurktur lanjutan, yang telah diinisiasi sejak 2017 yaitu program one home stay one toilet, yang juga merupakan CSR Desa Wisata Pulesari. Pemilik homestay diberikan dana sebesar Rp2.000.000,- (dua juta rupiah) per homestay untuk membuat toilet di setiap rumah atau menambah satu toilet di rumahnya.

Disisi lain dari segi penguatan kapasitas dan kelembagaan masyarakat yang telah dilakukan yaitu mengikuti pelatihan homestay selama 3 hari, pelatihan manajemen organisasi, dan pelatihan terkait kepemanduan. Untuk program jangka pendek akan dilakukan program review kembali tentang atraksi yang ada di Desa Wisata Pulesari, akan mengundang praktisi untuk memberi semangat kepada masyarakat/anggota dalam mengembangkan Desa Wisata Pulesari serta menambah kekompakan dalam mewujudkan komitmen bersama dalam kegiatan pariwisata yang untuk penguatan kapasitasnya.

Seiring meningkatnya pengetahuan masyarakat akan program pengembangan desa wisata maka semakin meningkat pula kunjungan wisatawan ke Desa Wisata Pulesari. Berikut ini merupakan data kunjungan wisatawan empat tahun terakhir di Desa Wisata Pulesari: 
Tabel 2. Kunjungan Wisatawan dan Omset Desa Wisata Pulesari Tahun 2015-2018

\begin{tabular}{lccc}
\hline Tahun & $\begin{array}{c}\text { Wisatawan } \\
\text { Mancanegara }\end{array}$ & $\begin{array}{c}\text { Wisatawan } \\
\text { Nusantara }\end{array}$ & Omset \\
\hline 2015 & 28 & 50.271 & 1.448 .500 .000 \\
2016 & 32 & 52.947 & 2.159 .286 .000 \\
2017 & 47 & 63.927 & 3.284 .583 .000 \\
2018 & 185 & 72.738 & 4.507 .846 .000 \\
\hline
\end{tabular}

Sumber: Desa Wisata Pulesari, 2019

Dari data diatas dapat terlihat bahwa seiring dengan meningkatnya kunjungan wisatawan ke Desa Wisata Pulesari disetiap tahunnya, maka semakin meningkat pula pendapatan Desa Wisata Pulesari. Peningkatan pendapatan desa berpengaruh terhadap meningkatkan pendapatan masyarakat Desa Wisata Pulesari. Peningkatan pendapatan masyarakat ini memberikan kesejahteraan kepada seluruh masyarakat Dusun Pulesari, terutama masyarakat petani salak.

Sementara itu, lima tahun terakhir ini Desa Wisata Pulesari merupakan desa wisata yang memiliki kunjungan terbanyak diantara desa wisata lainnya di Sleman. Berikut ini merupakan data kunjungan desa wisata di Sleman: 
Tabel 3. Kunjungan Wisatawan ke Sleman Tahun 2014-2018

\begin{tabular}{|c|c|c|c|c|c|}
\hline \multirow{2}{*}{ Desa Wisata } & \multicolumn{5}{|l|}{ Tahun } \\
\hline & 2014 & 2015 & 2016 & 2017 & 2018 \\
\hline Bokesan & 1.840 & 1.722 & 2.231 & - & - \\
\hline Brajan & 2.845 & - & 1.008 & - & 1.975 \\
\hline Brayut & 17.458 & 2.750 & 1.096 & - & 1.576 \\
\hline Candi Abang & - & - & - & - & - \\
\hline Dukuh & - & - & 627 & - & 869 \\
\hline Gabugan & 2.711 & 975 & 1.571 & 1.628 & 1.429 \\
\hline Gamplong & - & 5.375 & 1.700 & 5.675 & 29.373 \\
\hline Garongan & - & 9.301 & 12.025 & 15.680 & 10.440 \\
\hline Grogol & 2.589 & 2.160 & 14.808 & 12.476 & 8.193 \\
\hline Jetak & 1.444 & 1.540 & 2.601 & 1.829 & 480 \\
\hline Kadisobo & - & 3.144 & - & - & - \\
\hline Kedung Nganten & - & - & - & - & 609 \\
\hline Kelor & 7.890 & 8.822 & 12.058 & 11.680 & 17.581 \\
\hline Kembangarum & - & 16.620 & - & - & - \\
\hline Ketingan & 571 & 240 & 380 & - & 102 \\
\hline Kinahrejo & - & - & - & - & - \\
\hline Ledoknongko & 2.120 & 3.493 & 2.165 & - & 934 \\
\hline Malangan & 824 & - & - & - & 482 \\
\hline Mlangi & - & - & 1121 & - & 31.223 \\
\hline Nawung & 432 & 1.661 & 1.199 & - & 844 \\
\hline Nanggring & 211 & 2.089 & - & 1.820 & - \\
\hline Pancoh & 728 & 787 & 2.516 & 6.102 & 10.795 \\
\hline Pajangan & - & - & - & - & - \\
\hline
\end{tabular}




\begin{tabular}{lclllc}
\hline Pentingsari & 25.823 & 29.185 & 32.508 & 20.417 & 23.465 \\
\hline Plempoh & 25.700 & 500 & 929 & - & 2.775 \\
\hline Pulesari & $\mathbf{3 2 . 1 7 8}$ & $\mathbf{5 0 . 2 7 1}$ & $\mathbf{5 2 . 9 4 7}$ & $\mathbf{6 3 . 9 2 7}$ & $\mathbf{7 2 . 9 2 3}$ \\
\hline Pulewulung & 3.250 & - & - & - & 2.502 \\
\hline Rejosari & - & - & - & - & 237 \\
\hline Rumah Domes & 23.049 & 27.893 & 30.255 & 61.027 & 35.356 \\
\hline Sendari & 1.888 & 1.543 & - & - & - \\
\hline Srowolan & 29.748 & 29.748 & - & - & - \\
\hline Sukunan & 4.670 & 6.218 & - & - & 8.043 \\
\hline Tanjung & 9.945 & 4.197 & 300 & 1.957 & 1.878 \\
\hline Tlatar & - & - & - & - & - \\
\hline Trumpon & 1.830 & - & - & - & - \\
\hline Tunggularum & 2.266 & 1.413 & - & 3.675 & 3.128 \\
\hline
\end{tabular}

Sumber: Dinas Pariwisata Sleman, 2019

Berdasarkan tabel diatas, dapat dilihat lima tahun terakhir ini, Desa Wisata Pulesari merupakan desa wisata dengan kunjungan tertinggi di wilayah Sleman. Hal tersebut disebabkan program pengembangan desa wisata, yang mendapatkan dukungan penuh oleh masyarakat desa. Proses perubahan tersebut berdampak terhadap meningkatnya jumlah wisatawan, sehingga berpengaruh terhadap meningkatnya perekonomian desa dan berdampak pada bertambahnya peluang pekerjaan sehingga meningkatkan penghasilan masyarakatnya.

Atraksi wisata yang menjadi primadona di Desa Wisata Pulesari adalah atraksi tracking di sungai yang dikelilingi perkebunan salak masyarakat. Berikut ini merupakan gambaran dari araksi tracking sungai yang berada di Desa Wisata Pulesari: 


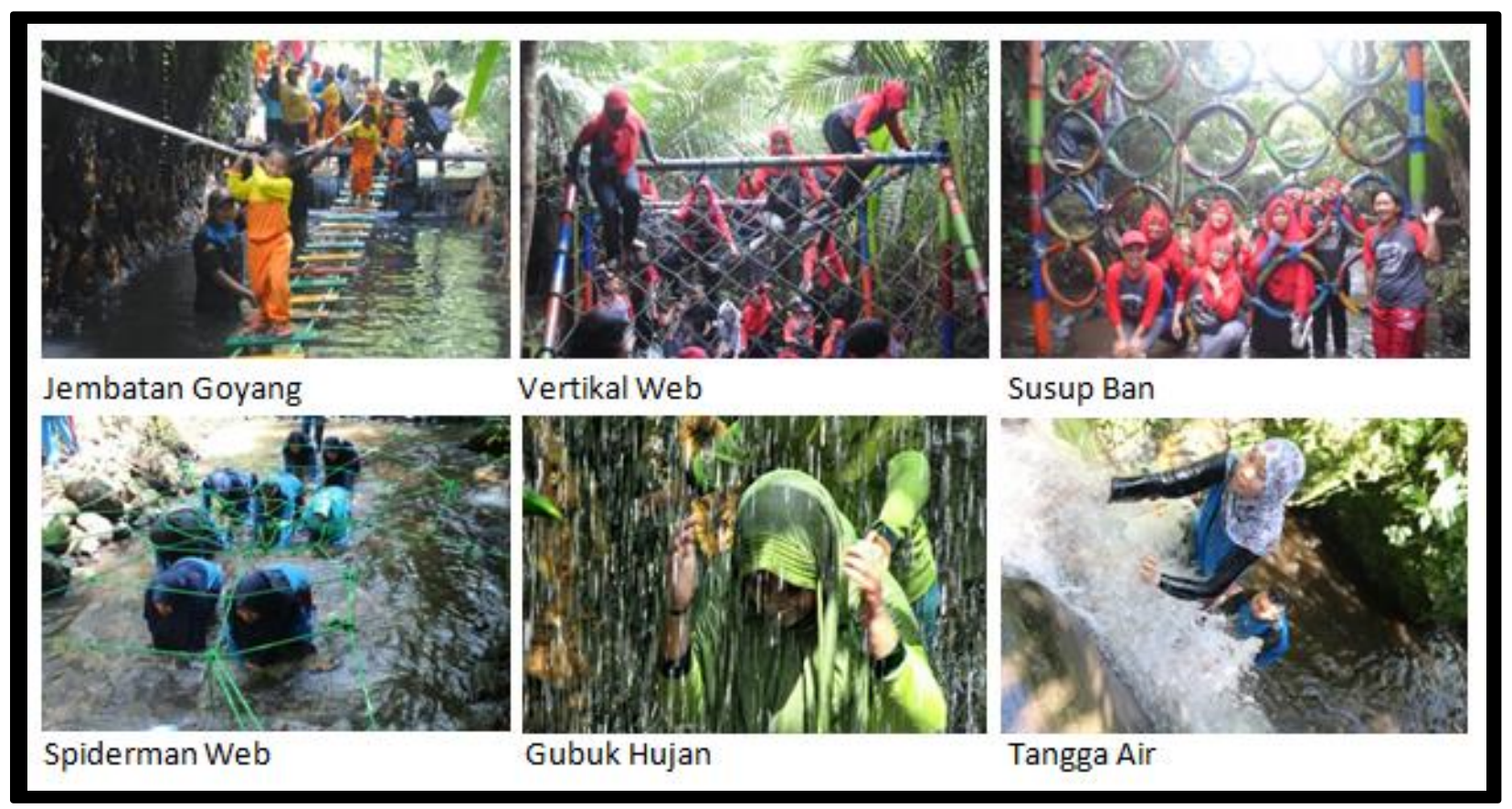

Gambar 2. Atraksi Tracking Sungai di Desa Wisata Pulesari Sumber: Dokumentasi Desa Wisata Pulesari

Selain tracking sungai, atraksi lainnya yang menjadi favorit di Desa Wisata Pulesari adalah outbond. Untuk mengikuti kegiatan outbond di Dusun Pulesari wisatawan akan dipandu oleh trainer profesional, kegiatan outbond dilakukan area pendopo dan kolam. Kegiatan yang dilakukan di kolam meliputi titian bambu, jembatan tali dan tangkap ikan.

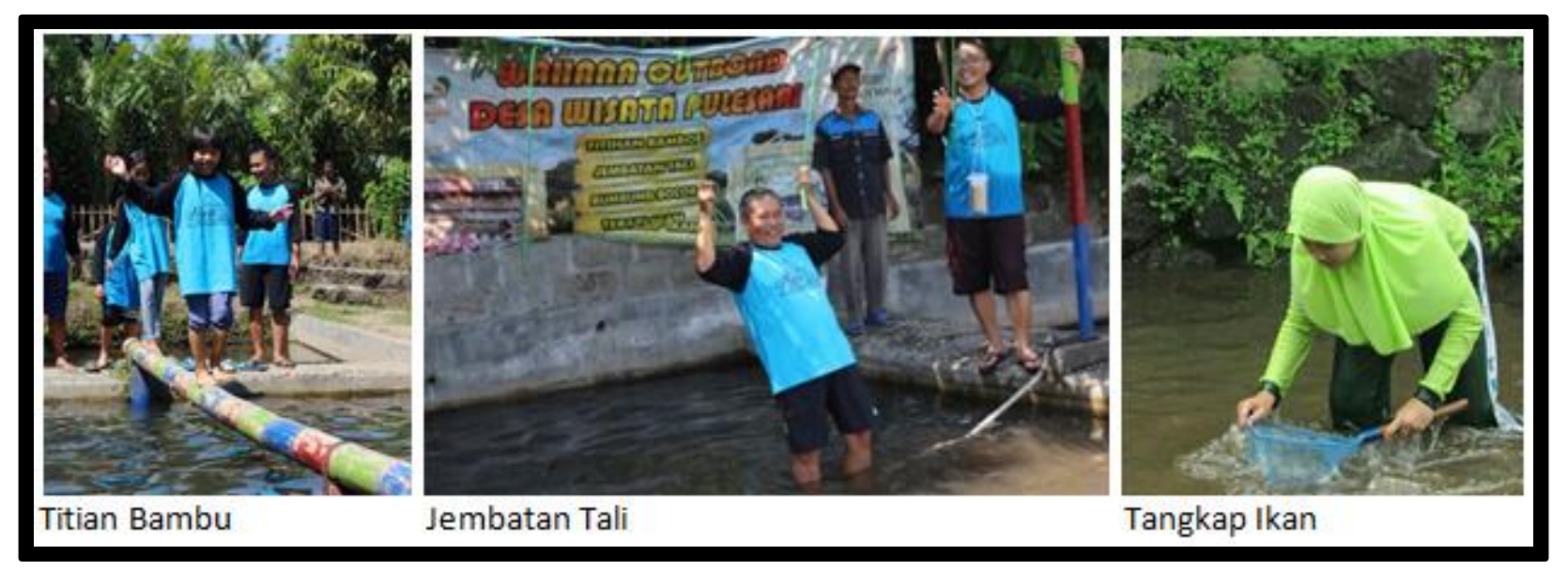

Gambar 3. Atraksi Outbond di Kolam Desa Wisata Pulesari Sumber: Dokumentasi Desa Wisata Pulesari 
Setelah melakukan tracking sungai dan outbond, wisatawan dapat melakukan selfie di area sungai, berikut ini merupakan spot selfie favorit wisatawan:

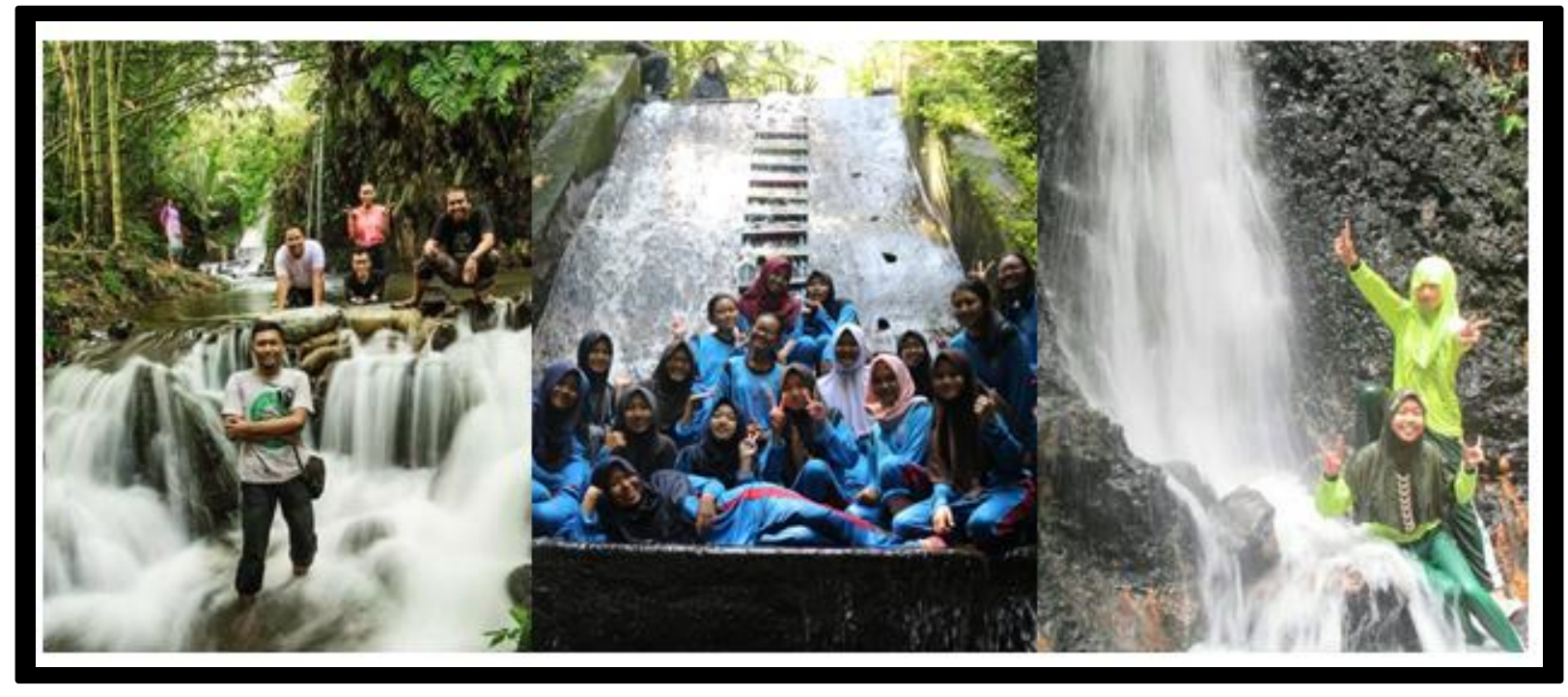

Gambar 4. Spot Selfie di Sungai Desa Wisata Pulesari Sumber: Dokumentasi Desa Wisata Pulesari

\section{Strukturasi dalam Pengembangan Desa Wisata Pulesari}

Struktur masyarakat di Dusun Pulesari telah memiliki nilai dan sistem kehidupan sendiri. Beragam komponen kehidupan tersebut merupakan struktur yang diwariskan atau terwariskan secara alamiah ataupun dipaksakan kepada masyarakat sebagai "eksternal constrains". Struktur yang sudah menjadi budaya dalam masyarakat ini mengalami metamorfosis dengan adanya pengembangan Dusun Pulesari menjadi Desa Wisata Pulesari. Dualitas struktur terjadi dalam sistem kehidupan mereka yang tidak dapat dihindari. Ketika masyarakat menjadi warga Dusun Pulesari, mereka menjadi bagian dari suatu entitas masyarakat yang besar. Mereka harus mematuhi aturan-aturan umum yang diberlakukan desa. Disisi lain, masyarakat juga merupakan bagian dari Desa Wisata Pulesari yang merupakan sebuah organisasi dalam Dusun Pulesari, sehingga mereka juga harus mematuhi aturan-aturan yang diberlakukan dalam desa wisata. Misalkan dalam hal gotong royong, jika kegiatan gotong royong merupakan kegiatan dusun, maka seluruh 
masyarakat desa secara sukarela meluangkan waktu dan tenaga tanpa mendapat imbalan untuk melaksanakan gotong royong. Berbeda jika kegiatan gotong royong merupakan kegiatan desa wisata, maka masyarakat yang mengikuti kegiatan gotong royong akan mendapatkan imbalan dari desa wisata.

Pada awal berdiri Desa Wisata Pulesari memiliki 1 ketua dan 1 wakil ketua, 4 sekretariat (kunjungan wisata \& promosi, administrasi keuangan, tata usaha umum, dan pemberdayaan SDM). Selanjutnya terdapat seksi dalam kepengurusan Desa Wisata Pulesari yaitu seksi pemandu terdiri dari 7 kelompok, seksi dasha wisma (catering) terdiri dari 6 kelompok, seksi among tamu terdiri dari 21 orang, seksi kemanan dan kesehatan 5 orang, seksi kesenian dan kerajinan terdiri dari 1 kelompok, seksi unit pengelolaan sampah terdiri dari 1 kelompok, seksi kebersihan terdiri dari 1 kelompok, serta seksi seni dan budaya terdiri dari 1 kelompok.

Teori sturkturasi menilai, pengelola memiliki dominasi dalam pengembangan Desa Wisata Pulesari. Struktur dominasi merupakan penguasaan atas orang (politik) ataupun barang/hal (ekonomi). Dalam penelitian ini, pengelola dinilai memiliki peran yang dominan diantara agen lainnya, karena saran dan masukan yang diajukan masyarakat tidak dapat berlangsung tanpa persetujuan pengelola. Dengan dominasi yang dimiliki pengelola, kebijakan pengembangan seperti apa yang akan dijalankan di Desa Wisata Pulesari ditentukan oleh pengelola. Akhirnya berdasarkan musyawarah dengan seluruh warga desa, pengelola memutuskan ada 7 (tujuh) program unggulan Desa Wisata Pulesari yang akan dilaksanakan untuk pengembangan desa wisata, yaitu: STD ( Sustainable Tourism Devolepment), One Homestay One Toilet, Tamanisasi Pagar Desa, Jaminan Sosial Mandiri 'Dewi Pule', Koperasi ‘Dewi Pule', UKM Mart 'Dewi Pule', serta Pasar Kebun dan Cafe Kebun.

Ditetapkannya program unggulan tersebut berkaitan dengan rasionalitas tindakan agen-agen yang terlibat di dalamnya, seperti pengelola desa wisata, komunitas desa wisata, dan masyarakat desa wisata. Menurut Giddens, karakteristik 
perilaku manusia yang rutin dilakukan secara biasa merupakan proses rasionalisasi, tindakan rasionalisasi merupakan tindakan yang sengaja (intentionality) dilakukan (Giddens, 2010). Program pengembangan desa wisata ini sengaja dilaksanakan dengan program-program yang dianggap sesuai untuk mengembangkan desa wisata serta dapat dilaksanakan oleh masyarakat desa.

Program pengembangan desa wisata telah dilakukan terus menerus sejak Desa Wisata Pulesari berdiri, masyarakat desa pun melaksanakan program yang telah disepakati tanpa perdebatan karena dilakukan dengan terbiasa, hal tersebut yang dimaksud rasionalisasi tindakan. Giddens menjelaskan rasionalisasi tindakan yang dimiliki agen mempertahankan suatu "pemahaman teoritis' yaitu terus menerus melakukan aktivitasnya (Giddens, 2010). Proses dan tindakan dijalankan bertahuntahun dan dilakukan secara terus-menerus sehingga memunculkan suatu praktik sosial. Praktik sosial yang muncul mengenai kegiatan program pengembangan Desa Wisata Pulesari. Praktik sosial terbentuk karena adanya prinsip-prinsip struktural mendasar, yang terdapat dalam struktur.

Dasar dari prinsip-prinsip struktural tersebut yaitu signifikasi, dominasi, dan legitimasi. Ketiga gugus struktur tersebut akan menunjukkan agen-agen yang terlibat dalam praktik sosial pengembangan Desa Wisata Pulesari. Hasil penelitian menunjukkan, agen yang terlibat dalam pengembangan Desa Wisata Pulesari adalah pihak pengelola dalam hal ini diwakili oleh ketua, wakil ketua, tim sekretariat, dan kepala seksi-seksi Desa Wisata Pulesari dan masyarakat Desa Pulesari sebagai pelaksana dari program pengembangan Desa Wisata Pulesari.

Praktik sosial yang terjadi dalam pengembangan Desa Wisata Pulesari dimulai dengan adanya Surat Keputusan Kepala Dinas Kebudayaan dan Pariwisata Kabupaten Sleman Nomor 556/10/2015 tentang Pengukuhan Kelompok Sadar Wisata Dewi Pule Desa Wisata Pulesari, Wonokerto, Kecamatan Turi, Kabupaten Sleman. Peraturan tersebut menunjukkan bahwa pelaku kepariwisataan (dalam hal ini 
pengelola desa wisata) peduli dan bertanggung jawab serta berperan sebagai penggerak dalam mendukung terciptanya iklim yang kondusif dalam mengembangkan desa wisata dan agar dapat bermanfaat bagi kesejahteraan masyarakat. Peraturan tersebut merupakan legitimasi tertulis bagi pengelola desa wisata. Legitimasi tidak sepenuhnya dimiliki pengelola, masyarakat desa berhak untuk mengawasi implementasi peraturan tersebut.

Giddens berpandangan bahwa norma merupakan jembatan yang mengarahkan legitimasi. Pengembangan desa wisata adalah program pengelola dalam upaya mensejahterakan masyarakat, hal tersebut adalah salah satu norma dalam masyarakat. Selama ini masyarakat meyakini bahwa masalah pengembangan desa wisata adalah tanggung jawab pengelola. Pengelola desa wisata bertugas melaksanakan kegiatan pengembangan desa wisata dengan sebaik-baiknya. Apabila pengelolaan Desa Wisata Pulesari dalam hal ini pengembangan Desa Wisata Pulesari tidak dilaksanakan, akan ada sanksi yang diterima pengelola, yaitu sanksi administratif yang diberikan Dinas Kebudayaan dan Pariwisata Kabupaten Sleman dan sanksi sosial dari masyarakat desa. Tidak ada aturan yang menjelaskan bagaimana pengembangan desa wisata seharusnya dilakukan, sehingga pengelola selaku pelaksana kebijakan memiliki kekuasaan dalam menginterpretasikan pengelolaan desa wisata menurut pemikiran mereka. Pengelola mengartikan bahwa kegiatan pengembangan desa wisata dapat diwujudkan melalui program-program unggulan yang sebelum ditetapkan, telah dimusyawarahkan terlebih dahulu dengan seluruh masyarakat desa. Bentuk kegiatan program-program unggulan tersebut merupakan dominasi yang dimiliki oleh pengelola desa wisata selaku pelaksana kebijakan.

Sebagai pihak yang bertanggung jawab atas kesejahteraan masyarakat, maka pengelola Desa Wisata Pulesari berupaya membuat program-program yang dapat mengedukasi masyarakat dengan kegiatan yang dapat berkontribusi terhadap desa 
dan masyarakat serta menghasilkan peningkatan penghasilan masyarakat dengan bertambahnya lapangan pekerjaan sehingga dapat menjadikan masyarakat sejahtera.

Dalam proses tersebut, terjadi perjumpaan antara pihak masyarakat desa dengan pengelola desa wisata. Dalam musyawarah mengenai program-program yang akan dilaksanakan sebagai program unggulan Desa Wisata Pulesari masyarakat desa bebas mengeluarkan pendapat dan usulan. Namun, dengan kuasa yang dimiliki pengelola berhak menentukan usulan siapa saja yang akan dijadikan sebagai program unggulan Desa Wisata Pulesari. Dominasi dalam teori strukturasi memiliki dua poin penting, yaitu penguasaan atas orang dan penguasaan atas barang/hal. Pengelola memiliki penguasaan atas barang/hal. Pengelola berkuasa untuk menentukan hal apa saja yang akan menjadi prioritas untuk pengembangan Desa Wisata Pulesari, siapa saja yang akan melaksanakan program tersebut, anggaran yang akan digunakan untuk program tersebut serta segala hal yang berkaitan dengan kegiatan pengembangan tersebut. Terkait dengan penguasaannya terhadap program pengembangan desa wisata, pengelola juga melakukan pengaturan terhadap waktu pelaksanaan program.

Selanjutnya, dimensi sukturasi signifikasi yang terlihat jelas dalam penelitian ini adalah pelaksanaan program-program unggulan Desa Wisata Pulesari yang merupakan simbol/bentuk dari program pengembangan desa wisata yang diadakan oleh pengelola bagi masyarakat Desa Pulesari. Pelaksanaan program-program unggulan yang telah ditetapkan dilakukan bersama-sama oleh pengurus dan masyarakat yang dianggap memiliki kemampuan dan pengalaman yang terkait dengan program tersebut.

Pada hakikatnya, pelaksanaan program unggulan Desa Wisata Pulesari ini tidak hanya sekedar memberikan edukasi kepada masyarkat tetapi juga memberikan modal kepada masyarakat misalnya dalam program One Homestay One Toilet yang dilaksankan bertahap 2017-2019. Pada saat program ini belum ada, banyak 
masyarakat desa yang belum memiliki toilet atau kamar mandi di rumahnya, namun pada saat ini semua rumah di Desa Pulesari telah memiliki toilet. Berikut ini merupakan skema praktik sosial pengembangan Desa Wisata Pulesari bagi masyarakat Dusun Pulesari yang tersusun dari tiga prinsip utama struktural:

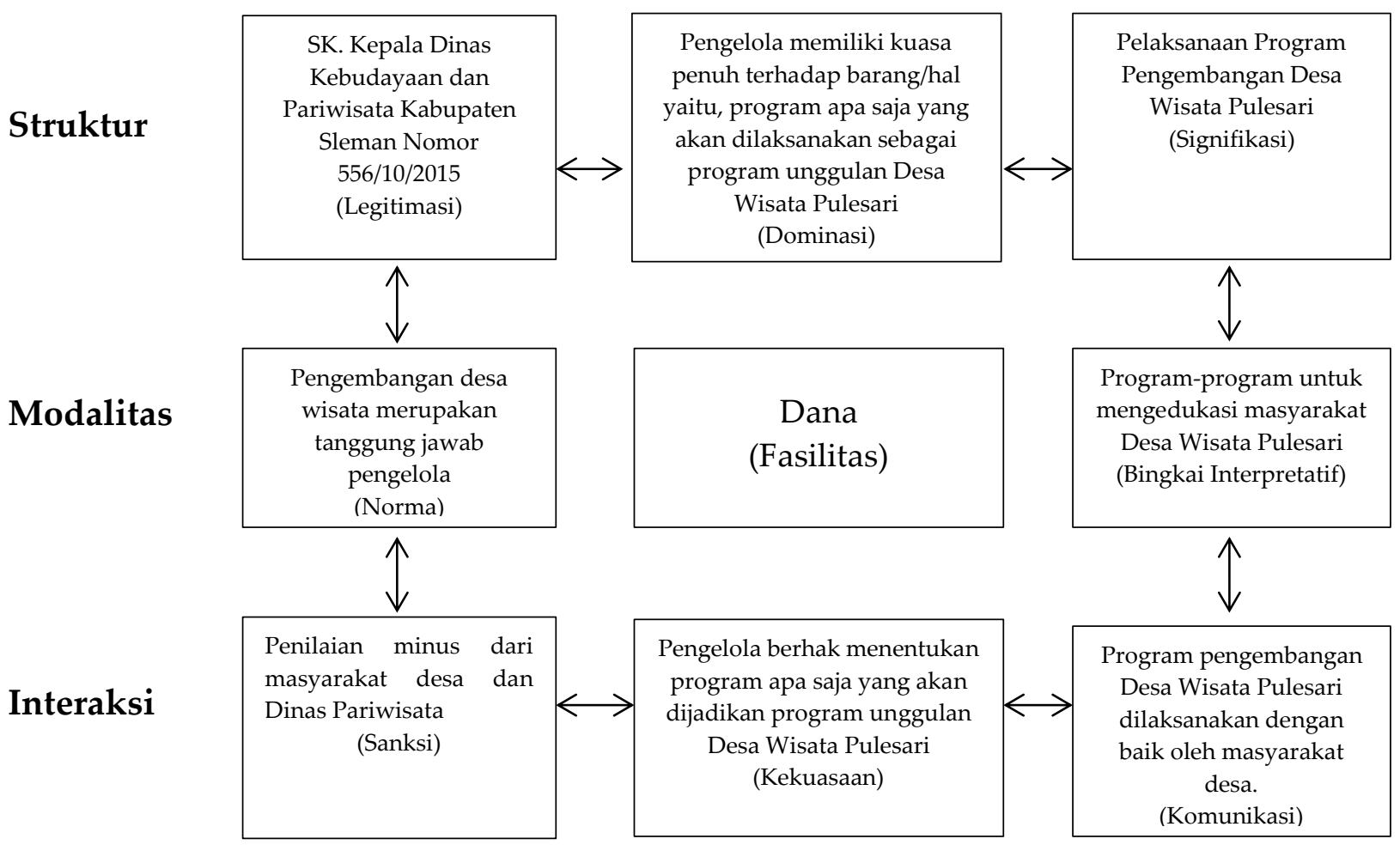

Gambar 5. Skema Praktik Sosial Pengembangan Desa Wisata Pulesari

Sumber: Data olahan peneliti, 2019

\section{Kesimpulan dan Saran}

Program pengembangan desa wisata yang telah ditetapkan oleh pengelola sebagian besar telah berjalan sesuai rencana. Pengelola menjalankan kebijakan pengembangan Desa Wisata Pulesari melalui tujuh program unggulan yaitu, STD (Sustainable Tourism Devolepment), One Homestay One Toilet, Tamanisasi Pagar Desa, Jaminan Sosial Mandiri 'Dewi Pule', Koperasi ‘Dewi Pule', UKM Mart 'Dewi Pule' serta Pasar Kebun dan Cafe Kebun. Dari ketujuh program tersebut hanya 2 (dua) program yang belum berjalan yaitu UKM Mart 'Dewi Pule' serta Pasar Kebun dan Cafe Kebun. Dengan berbagai program yang telah berjalan, hal ini mempengaruhi 
kunjungan wisatawan ke Desa Wisata Pulesari. Semakin meningkatnya kunjungan wisatawan maka semakin meningkat pula perekonomian desa dan masyarakat Desa Wisata Pulesari. Hal ini berarti juga meningkatkan perekonomian petani salak dari program pengembangan desa wisata. Program-program unggulan, menjadi suatu praktik sosial yang dilakukan secara terus menerus dan berulang-ulang. Praktik sosial tersebut diulas dalam prinsip utama struktural, yaitu legitimasi, dominasi, dan signifikasi. Regulasi yang ada mengharapkan pengelola dapat mengembangkan desa wisata agar masyarakat desa sejahtera. Sayangnya tidak dijelaskan bagaimana pengembangan seharusnya dilakukan. Sehingga pengelola memiliki pandangannya sendiri mengenai pengembangan desa wisata bagi masyarakat desa. Pengelola Desa Wisata Pulesari sebagai pihak yang berkuasa mengartikan pengembangan desa wisata dengan melaksanakan program-program unggulan yang telah ditetapkan berdasarkan musyawarah bersama masyarakat desa.

\section{Ucapan Terima Kasih}

Terima kasih kepada kelompok pelaku pariwisata, tokoh masyarakat, dan birokrasi yang ada di Desa Wisata Pulesari, Desa Wonokerto, Kecamatan Turi, Kabupaten Sleman, Provinsi Daerah Istimewa Yogyakarta yang telah mewujudkan penelitian ini. Hasil penelitian dalam artikel ini merupakan bagian dari penelitian empiris yang berkaitan dengan Program Penelitian Hibah PNBP Tahun 2019 Universitas Sebelas Maret, Surakarta, Indonesia. 


\section{Daftar Pustaka}

Afrizal. 2015. Metode Penelitian Kualitatif: Sebuah Upaya Mendukung Penggunaan Penelitian Kualitatif dalam Berbagai Disiplin Ilmu. Jakarta. RajaGrafindo Persada.

Andini, N. 2013. "Pengorganisasian Komunitas dalam Pengembangan Agrowisata di Desa Wisata Studi Kasus Desa Wisata Kembangarum, Kabupaten Sleman." Jurnal Perencanaan Wilayah dan Kota, 24 (3), 173-188.

Anugrah dan Sudarmayasa. 2017. Pembangunan Pariwisata Daerah Melalui Pengembangan Sumber Daya Manusia di Gorontalo. Jurnal JUMPA, 4 (1), 3346.

Arifin dan Yen. 2017. "Sustainable Agrotourism Curating by Conferring Community Involvement in Tanah Rata, Cameron Highlands, Malaysia." Journal of Design and Built Environment, Special Issue 2017, 38-52.

Chamdani, U. 2018. Komunikasi Dua Tahap dan Agrowisata. Yogyakarta: Budi Utama.

Cislaghi, et. al. 2016. Values Deliberation and Collective Action: Community Empowerment in Rural Senegal. London: Palgrave Macmillan.

Giaccio et al. 2015. "Is Agrotourism Eco-friendly? A Comparison Between Agrotourisms and other Farms in Italy using Farm Accountancy data Network Dataset." SpringerPlus 4(1), 1-12.

Giddens, A. 2010. Teori strukturasi: Dasar-dasar pembentukan struktur sosial di masyarakat. Yogyakarta: Pustaka Pelajar.

Giddens, A. 2011. The Constitution of Society. Yogyakarta: Pedati.

Janah, Eddy \& Dalmiyatun. 2017. "Alih Fungsi Lahan Pertanian dan Dampaknya terhadap Kehidupan Penduduk Kecamatan Sayung Kabupaten Demak." Jurnal Agrisocionomic, 1(1), 7-8.

Littlejhon \& Foss. 2009. Encyclopedia of Communication Theory. California: SAGE Publications.

Littlejhon \& Foss. 2011. Theories of Human Communication. USA: Waveland Press.

Palit et al. 2017. Strategi Pengembangan Kawasan Agrowisata Rurukan. Jurnal AgriSosio Ekonomi Unsrat, 13(2A), 21-34. 
Pambudi et al. 2018. Strategi Pengembangan Agrowisata dalam Mendukung Pembangunan Pertanian: Studi Kasus di Desa Wisata Kaligono (Dewi Kano) Kecamatan Kaligesing Kabupaten Purworejo. Jurnal Analisis Kebijakan Pertanian, 16 (2), 165-184.

Rahmadi, T. 2019. "Tantangan Pariwisata Indonesia di Era Jokowi-Ma'ruf Amin." Sumber:(https://mediaindonesia.com/read/detail/245213-tantanganpariwisata-indonesia-di-era-jokowi-maruf-amin), Diakses 09/10/2019.

Setyawati, E. Y. 2014. Pemberdayaan Masyarakat sebagai Upaya Peningkatan Perekonomian Masyarakat Pesisir Berdasarkan Kearifan Lokal. Yogyakarta: Universitas Atmajaya Yogyakarta.

Sudarmadji. 2014. Dampak Lingkungan dan Risiko Bencana Pengembangan Desa Wisata Studi Kasus di Desa Wisata Sambi. Kawistara, 4(2), 111-224.

Tibuludji, Mahendara dan Adhika. (2017). Dampak Pengembangan Pariwisata Terhadap Kehidupan Masyarakat Pesisir Lima, Kupang. Jurnal JUMPA, 4 (1), 91-104.

\section{Profil Penulis}

Kusuma Astuti, SP merupakan alumnus D3 Manajemen Informasi Kesehatan dan Rekam Medis Universitas Indonesia, S1 Sosial Ekonomi Pertanian Universitas Satyagama dan saat ini sedang menempuh studi sebagai mahasiswa S2 Magister Ilmu Komunikasi Universitas Sebelas Maret. Semasa studi S2 menerima Beasiswa dari Kementerian Pertanian. Bidang yang diminati dan ditekuni adalah ilmu komunikasi.

Prof Dr. Ismi Dwi Astuti Nurhaeni, M.Si., merupakan Profesor Administrasi Publik Fakultas Ilmu Sosial dan Ilmu Politik Universitas Sebelas Maret (UNS). Ia memperoleh gelar sarjana hingga doktor di bidang yang sama yaitu S1 Ilmu Administrasi Negara Universitas Sebelas Maret, S2 Ilmu Administrasi Negara dan S3 Administrasi Negara Universitas Gajah Mada. Dia merupakan ahli gender yang terlibat dalam pengarusutamaan gender di Indonesia sejak awal 2001. Cukup aktif dalam menulis artikel dan buku yang berkaitan dengan administrasi publik dan gender. Minat utama dalam penelitian mencakup studi gender dan administrasi publik. Selain itu, sejak 2015 ia telah menjadi dekan Fakultas Ilmu Sosial dan Ilmu Politik Universitas Sebelas Maret Surakarta. 
Dr. Andre Noevi Rahmanto, M.Si. merupakan alumnus S1 Komunikasi Massa dan S2 Manajemen Komunikasi Universitas Sebelas Maret dan S3 Ilmu Komunikasi Universitas Padjajaran. Saat ini merupakan dosen tetap Prodi Ilmu Komunikasi UNS. Bidang keahlian yang diminati adalah Strategic Communication dan Komunikasi Organisasi. Riset yang dilakukan antara lain mengenai topik City Branding, CSR dan Komunikasi Pariwisata. 